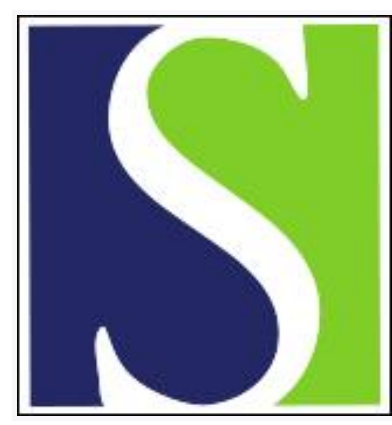

Scand J Work Environ Health 1991;17(5):312-317

https://doi.org/10.5271/sjweh.1697

Issue date: Oct 1991

\title{
Mortality among professional drivers.
}

by Rafnsson V, Gunnarsdottir H

Affiliation: Division of Occupational Medicine, Administration of Occupational Safety and Health, Reykjavik, Iceland.

This article in PubMed: www.ncbi.nlm.nih.gov/pubmed/1947916

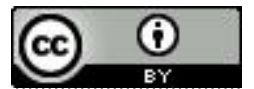




\title{
Mortality among professional drivers
}

\author{
by Vilhjálmur Rafnsson, MD, Hólmfriður Gunnarsdóttir, BA, ${ }^{1}$
}

\begin{abstract}
RAFNSSON V, GUNNARSDÓTTIR H. Mortality among professional drivers. Scand $J$ Work Environ Health 1991;17:312 - 7. The mortality of truck drivers and taxi drivers was studied in Reykjavík. The national mortality rate was used for comparison, and the follow-up lasted until 1 December 1988 . The 868 truck drivers (28 788.0 person-years) had an excess of lung cancer deaths [ 24 observed, 11.2 expected, standardized mortality ratio (SMR) 2.14], but fewer deaths than expected from respiratory diseases (15 observed versus 30.1 expected). The SMR from lung cancer did not steadily increase as the duration of employment increased, nor did it change with the length of follow-up. The SMR values did not deviate substantially from unity for the taxi drivers. Since the high mortality from lung cancer among the truck drivers did not seem to be due to their smoking habits, it might have been caused by one or more occupational factors, especially in light of this group's exposure to engine exhaust gases.
\end{abstract}

Key terms: exhaust gases, lung cancer, respiratory diseases, retrospective cohort study, smoking habits.

Retrospective studies among male truck drivers have revealed a higher mortality due to lung cancer than expected among men in general $(1,2)$. A Swedish incidence study which had a design similar to these mortality studies indicated that truck drivers were more likely to develop lung cancer than were other Swedish men (3). When the incidence of cancer among Danish bus drivers was investigated, there was no indication of an increased risk of lung cancer. More of these bus drivers developed skin and bladder cancer than expected, however (4).

In the United States and the United Kingdom retrospective mortality studies among taxi drivers have shown that the number of deaths due to lung cancer is higher than expected $(1,5)$, although one study of British taxi drivers did not produce the same results (2).

The results of a Swedish case-referent study which investigated the relationship between smoking and lung cancer revealed that the drivers smoked more than other men and that smoking was the main reason for the increased relative risk of lung cancer among them (6). The results of this Swedish study with regard to nonsmoking drivers indicated that these men were also at higher risk of dying of lung cancer than were other nonsmokers who were not professional drivers. The authors of the study suggested that the increased risk of lung cancer among elderly drivers who smoked could be attributed to the combined effects of smoking and some exposure on the job. The study also showed that the truck drivers were at higher risk of lung cancer than the other drivers, although the drivers in general were more prone to develop lung cancer than the referents were (6).

\footnotetext{
1 Division of Occupational Medicine, Administration of Occupational Safety and Health, Reykjavík, Iceland.
}

Reprint requests to: Dr V Rafnsson, Division of Occupational Medicine, Administration of Occupational Safety and Health, Bíldshöfda 16, 112 Reykjavik, Iceland.
In three case-referent studies (7-9) professional drivers were found to be at risk of bladder cancer. Other studies indicated that bladder cancer can be related to exposure to the exhaust gases of diesel engines especially $(10,11)$. In the two case-referent studies in which it was possible to assess the effects of smoking, this type of exposure did not appear to explain the increased relative risk of bladder cancer among the drivers $(7,9)$. In addition to the previously mentioned study of Danish bus drivers who were more likely to develop bladder cancer than were other Danish men (4), a case-referent study of diagnosed cancer cases in Copenhagen indicated that drivers were at a higher risk of bladder cancer than others, and the results showed that this risk appeared to be connected with their occupation rather than with smoking (12). Results from other studies have not indicated, however, any association between driving as a profession and bladder cancer $(13,14)$.

The results of two cohort studies indicated a higher mortality due to leukemia among truck drivers than other persons $(15,16)$, although this finding was not confirmed in another cohort study of drivers (2). The study investigated the mortality among different groups of drivers (ie, taxi drivers, truck drivers, and bus and coach drivers) (2). The standardized mortality ratio (SMR) values for stomach and lung cancer, bronchitis, emphysema, and asthma among truck drivers were significantly higher, while their SMR values for ischemic heart disease and stroke were lower than expected in comparison with the corresponding values for other men. For taxi drivers the SMR values for stomach and lung cancer, bronchitis, emphysema, and asthma were low, whereas that for ischemic heart disease was high. These results indicate that professional drivers do not comprise a uniform group and that taxi drivers and truck drivers should be treated separately. 
The present study is a retrospective cohort investigation of mortality among taxi and truck drivers with special emphasis on lung cancer.

\section{Subjects and methods}

Information on the truck drivers was obtained from the membership rolls of the Truck Drivers' Union Thróttur (Vörubílstjórafélagio $\mathrm{P}_{\text {róttur) in Maður og }}$ Bill (17). There were some errors in the lists, and some drivers were listed without their date of birth. To obtain more comprehensive information, we contacted the Union itself and thus gained access to the original membership registers and files. The subjects were enrolled in the study when they were first mentioned in one of the registers or files. Through the files it was also possible to follow the length of time each subject was a member of the union, and this period was set as the employment time. Once the individuals had been identified by their name and date of birth or by their name and home address, they could be located in the registers of inhabitants of the City of Reykjavik; each individual's occupation was also recorded in these registers. In this manner each driver's personal identification number was established. The truck drivers' union was founded in 1931 and is still the union to which all truck drivers in Reykjavík belong.

Information on the taxi drivers was obtained primarily from the membership rolls of the cooperative taxi agency Hreyfill in Hreyfilsmenn: saga og félagatal 1943-1988 (18). The Hreyfill cooperative was formed by taxi drivers in 1943. There were also other taxi drivers' organizations in Reykjavik at that time. The aforementioned membership register also contained some errors in the recording of names and dates of birth and death. Additional information thus had to be obtained from the original membership rolls of the cooperative organization and from later registers. Each individual was identified in a manner similar to that used in the case of the truck drivers. The subjects of the cohort of taxi drivers could be divided into members of the cooperative and nonmembers; the latter were hired by members of the cooperative and sometimes only worked for a short time.

The truck drivers all owned their own trucks and, in that sense, were self-employed. The trucks were of different kinds, but since approximately 1950 they were nearly all equipped with diesel-powered engines. The main task of the drivers was to drive and transport various material and freight, and the drivers often participated in or were the only persons loading and unloading the trucks. The majority of the truck drivers did a great deal of maintenance and repair work on their trucks, which consequently led to exposure to asbestos, lubricating materials, and welding fumes, in addition to their exposure to exhaust gases.

The taxi drivers who were members of the cooperative were all owners of their own cabs and had worked for several years as taxi drivers. Some of them had later hired other persons, who were also included in the cohort of taxi drivers, to drive their cabs for shorter or longer periods, in some cases for a number of years. It was possible to differentiate between members of the cooperative and other taxi drivers through the memberships rolls. The taxi drivers scattered their work throughout the $24-\mathrm{h}$ day. Their passengers were allowed to smoke until approximately 1980 , but since then smoking has been limited and is now mostly forbidden during a taxi ride. The taxi drivers did not repair their cars themselves to the extent that the truck drivers did. Both taxi and truck drivers have to pass a special course and examination to get a license as a taxi or truck driver.

Of the 1075 individuals listed in the registers of the truck drivers' organization there were 1021 who could be identified and were alive in 1951. (See table 1.) Twenty-eight truck drivers could not be identified. They had all ceased to work as drivers prior to 1946 . There were 888 individuals registered as taxi drivers; 879 were identified and found alive in 1951. (See table 1.) Some individuals had worked both as a taxi and a truck driver, and these $\mathbf{1 5 3}$ were separated from the other groups in the later stages of the study.

After the groups had been properly registered, they were record-linked with the National Register and the Register of Deceased, kept at the Statistical Bureau of Iceland, to establish the fate of each individual. The date of death was recorded for each decedent. This search was carried out with the use of the ten-digit personal identification number. The death certificates of all the deceased were subsequently obtained from the Statistical Bureau of Iceland. At the end of the study

Table 1. Formation of the cohorts.

\begin{tabular}{|c|c|c|}
\hline Group & Number & Total \\
\hline \multicolumn{3}{|l|}{ Truck drivers } \\
\hline Initial number of personal records & & 1075 \\
\hline $\begin{array}{l}\text { Incomplete data } \\
\text { Deceased prior to } 1951\end{array}$ & $\begin{array}{l}28 \\
26\end{array}$ & \\
\hline $\begin{array}{l}\text { Men who had worked at sometime } \\
\text { as a truck driver and who were } \\
\text { alive in } 1951\end{array}$ & & 1021 \\
\hline $\begin{array}{l}\text { Men also employed as a taxi } \\
\text { driver } \\
\text { Deceased after } 1951\end{array}$ & $\begin{array}{l}153 \\
417\end{array}$ & \\
\hline $\begin{array}{l}\text { Men who had worked only as a truck } \\
\text { driver and were alive } 1951\end{array}$ & & 868 \\
\hline \multicolumn{3}{|l|}{ Taxi drivers } \\
\hline Initial number of personal records & & 888 \\
\hline $\begin{array}{l}\text { Incomplete data } \\
\text { Deceased prior to } 1951\end{array}$ & $\overline{9}$ & \\
\hline $\begin{array}{l}\text { Men who had worked at sometime } \\
\text { as a taxi driver and who were } \\
\text { alive } 1951\end{array}$ & & 879 \\
\hline $\begin{array}{l}\text { Men also employed as a truck } \\
\text { driver } \\
\text { Deceased after } 1951\end{array}$ & $\begin{array}{l}153 \\
272\end{array}$ & \\
\hline $\begin{array}{l}\text { Men who had worked only as a taxi } \\
\text { driver and were alive } 1951\end{array}$ & & 726 \\
\hline
\end{tabular}


period it was possible to establish the fate of all those individuals who had been identified at the start. Three death certificates for taxi drivers were obtained from abroad, as these persons had all died in other countries. Two death certificates for truck drivers were also obtained from abroad. The fate of any individual who was reported by the National Register or the Register of Deceased as having immigrated was sought from relatives still living in Iceland.

Table 2 provides information on the individual truck driver's occupation as recorded on the death certificate. Only $\mathbf{4 2 . 2 \%}$ were classified as drivers or former drivers, and, on a similar proportion of the death certificates, no occupation was stated at all.

The cause of death was recorded according to the categories of the seventh revision of the International Classification of Diseases and Causes of Death (ICD) (19). Four different revisions of the classification had been used during the study period, and the underlying cause of death was recoded to the seventh revision because the Icelandic Cancer Registry uses it and it has

Table 2. Information on occupation from death certificates for truck drivers.

\begin{tabular}{lcc}
\hline Profession on death certificate & Number & Percent \\
\hline Truck driver & 45 & 10.8 \\
Driver & 131 & 31.4 \\
Other profession & 94 & 22.5 \\
Profession not indicated & 147 & 35.3 \\
\hline
\end{tabular}

been used in many former mortality and cancer incidence studies in Iceland.

The follow-up of these cohorts began in 1951 and continued to the end of 1988 . Mortality rates prior to 1951 were considered unreliable in part due to the fact that, up to that time, many death certificates were attested by clergymen.

Person-years were calculated for each group commencing in 1951 or at the date when each individual started his job and ending with his date of death or at the end of 1988 (20). The number of expected deaths was calculated on the basis of person-years for each five-year age category during the respective calendar years of the study period, multiplied by the cause and calendar-year specific mortality rate for Icelandic men.

The ratio between the observed and expected numbers, or the SMR, was then calculated with the $95 \%$ confidence interval on the assumption of a Poisson distribution (21).

Separate analyses were done on subcohorts according to the follow-up periods and accumulated years of employment. The calculation of the SMR, when the cohorts were divided according to accumulated years of employment, was done with a requirement for a latency period of 30 years. By requiring 30 years of latency, we eliminated the effect of selection of the subjects into different exposure groups $(22,23)$.

According to a study carried out by the National Association for the Prevention of Heart Diseases, Hjartavernd, in 1974-1976, fewer nonsmokers were found

Table 3. Observed and expected number of deaths, the standardized mortality ratio (SMR), and $95 \%$ confidence interval (95\% $\mathrm{Cl}$ ) for the 868 subjects who had worked only as a truck driver (person-years 28788.0 ).

\begin{tabular}{|c|c|c|c|c|}
\hline Cause of death ${ }^{a}$ & $\begin{array}{c}\text { Observed } \\
\text { deaths }\end{array}$ & $\begin{array}{l}\text { Expected } \\
\text { deaths }\end{array}$ & SMR & $95 \% \mathrm{Cl}$ \\
\hline All causes (001-E985) & 362 & 381.8 & 0.95 & $0.86-1.05$ \\
\hline Malignant neoplasms (140-205) & 98 & 83.0 & 1.18 & $0.96-1.44$ \\
\hline $\begin{array}{l}\text { Stomach (151) } \\
\text { Large intestine }(152,153) \\
\text { Rectum (154) } \\
\text { Pancreas (157) } \\
\text { Trachea, bronchus and lung }(162,163) \\
\text { Prostate }(177) \\
\text { Kidney (180) } \\
\text { Bladder and other urinary organs (181) } \\
\text { Brain and other parts of the nervous }\end{array}$ & $\begin{array}{r}19 \\
7 \\
1 \\
8 \\
24 \\
9 \\
6 \\
3\end{array}$ & $\begin{array}{r}20.7 \\
5.6 \\
2.1 \\
5.3 \\
11.2 \\
8.8 \\
3.4 \\
3.0\end{array}$ & $\begin{array}{l}0.92 \\
1.25 \\
0.48 \\
1.50 \\
2.14 \\
1.02 \\
1.77 \\
1.02\end{array}$ & $\begin{array}{l}0.55-1.43 \\
0.50-2.58 \\
0.01-2.68 \\
0.65-2.96 \\
1.37-3.18 \\
0.47-1.93 \\
0.65-3.85 \\
0.21-2.97\end{array}$ \\
\hline $\begin{array}{l}\text { Brain and other parts of the nervous } \\
\text { system (193) }\end{array}$ & 3 & 2.1 & 1.40 & $0.29-4.10$ \\
\hline $\begin{array}{l}\text { Lymphoma }(200) \\
\text { Hodgkin's disease (201) } \\
\text { Leukemia and aleukemia (204) } \\
\text { Other neoplasms of lymphatic and }\end{array}$ & $\frac{1}{2}$ & $\begin{array}{l}0.6 \\
0.4 \\
2.5\end{array}$ & $\begin{array}{l}1.72 \\
0 \\
0.79\end{array}$ & $\begin{array}{l}0.04-9.61 \\
0.10-2.84\end{array}$ \\
\hline $\begin{array}{l}\text { hematopoietic tissue }(202,203,205) \\
\text { Other neoplasms }\end{array}$ & $\begin{array}{r}4 \\
11\end{array}$ & $\begin{array}{r}1.7 \\
15.4\end{array}$ & $\begin{array}{l}2.30 \\
0.71\end{array}$ & $\begin{array}{l}0.63-5.89 \\
0.36-1.28\end{array}$ \\
\hline Cerebrovascular diseases $(330-334)$ & 38 & 34.6 & 1.10 & $0.78-1.51$ \\
\hline Ischemic heart disease (420) & 129 & 117.4 & 1.10 & $0.92-1.31$ \\
\hline Respiratory diseases $(470-527)$ & 15 & 30.1 & 0.50 & $0.28-0.82$ \\
\hline $\begin{array}{l}\text { Accidents, poisonings and violence } \\
\text { (E800-E985) }\end{array}$ & 33 & 29.1 & 1.13 & $0.78-1.59$ \\
\hline Suicide (E963, E970-9) & 7 & 6.5 & 1.08 & $0.44-2.23$ \\
\hline All other causes & 49 & 87.8 & 0.56 & $0.41-0.74$ \\
\hline
\end{tabular}

\footnotetext{
a Code of the International Classification of Diseases (seventh revision) in parentheses.
} 
Table 4. Observed and expected number of deaths, the standardized mortality ratio (SMR), and $95 \%$ confidence interval ( $95 \%$ Cl) for the 726 subjects who had worked only as a taxi driver (person-years 19284.0 ).

\begin{tabular}{|c|c|c|c|c|}
\hline Cause of deatha & $\begin{array}{l}\text { Observed } \\
\text { deaths }\end{array}$ & $\begin{array}{l}\text { Expected } \\
\text { deaths }\end{array}$ & SMR & $95 \% \mathrm{Cl}$ \\
\hline All causes (001-E985) & 217 & 211.8 & 1.02 & $0.91-1.13$ \\
\hline Malignant neoplasms (140-205) & 49 & 50.4 & 0.97 & $0.72-1.29$ \\
\hline $\begin{array}{l}\text { Stomach (151) } \\
\text { Large intestine }(152,153) \\
\text { Rectum }(154) \\
\text { Pancreas (157) } \\
\text { Trachea, bronchus and lung }(162,163) \\
\text { Prostate (177) } \\
\text { Kidney (180) } \\
\text { Bladder and other urinary organs (181) } \\
\text { Brain and other parts of the nervous }\end{array}$ & $\begin{array}{r}6 \\
3 \\
-6 \\
12 \\
8 \\
4 \\
1\end{array}$ & $\begin{array}{r}11.3 \\
3.5 \\
1.3 \\
3.4 \\
8.6 \\
4.8 \\
2.0 \\
1.8\end{array}$ & $\begin{array}{l}0.53 \\
0.87 \\
0 \\
1.76 \\
1.39 \\
1.67 \\
1.97 \\
0.55\end{array}$ & $\begin{array}{r}0.19-1.15 \\
0.18-2.53 \\
\quad . \\
0.65-3.83 \\
0.72-2.43 \\
0.72-3.30 \\
0.54-5.05 \\
0.01-3.08\end{array}$ \\
\hline system (193) & 1 & 1.6 & 0.63 & $0.02-3.48$ \\
\hline $\begin{array}{l}\text { Lymphoma (200) } \\
\text { Hodgkin's disease (201) } \\
\text { Leukemia and aleukemia (204) } \\
\text { Other neoplasms of lymphatic and }\end{array}$ & $\frac{-}{-}$ & $\begin{array}{l}0.3 \\
0.3 \\
1.6\end{array}$ & $\begin{array}{l}0 \\
0 \\
0\end{array}$ & $\begin{array}{l}\cdot \\
\cdot\end{array}$ \\
\hline $\begin{array}{l}\text { hematopoietic tissue }(202,203,205) \\
\text { Other neoplasms }\end{array}$ & $\begin{array}{l}1 \\
7\end{array}$ & $\begin{array}{l}1.2 \\
8.7\end{array}$ & $\begin{array}{l}0.85 \\
0.81\end{array}$ & $\begin{array}{l}0.02-4.72 \\
0.32-1.66\end{array}$ \\
\hline Cerebrovascular diseases $(330-334)$ & 14 & 16.8 & 0.84 & $0.46-1.40$ \\
\hline Ischemic heart disease $(420)$ & 76 & 71.4 & 1.06 & $0.84-1.33$ \\
\hline Respiratory diseases $(470-527)$ & 19 & 13.6 & 1.40 & $0.79-2.10$ \\
\hline $\begin{array}{l}\text { Accidents, poisonings and violence } \\
\text { (E800-E985) }\end{array}$ & 24 & 21.8 & 1.10 & $0.70-1.64$ \\
\hline Suicide (E963, E970-9) & 7 & 5.0 & 1.39 & $0.56-2.87$ \\
\hline All other causes & 35 & 37.9 & 0.92 & $0.64-1.28$ \\
\hline
\end{tabular}

a Code of the International Classification of Diseases (seventh revision) in parentheses.

among truck drivers than among other men in Reykjavík (24). We searched for the drivers in the data of Hjartavernd using record linkage to examine the smoking habits in more detail. In that way information was obtained as to the smoking habits of those who were on record in the Hjartavernd study.

\section{Results}

Table 3 shows the results for those who worked only as truck drivers. The SMR for malignant neoplasms was higher than expected, especially for lung cancer, other neoplasms of lymphatic and hematopoietic tissue, lymphoma, and cancer of the kidneys. There was low mortality from respiratory diseases (15 observed, 30.1 expected).

Table 4 shows the results for those who worked only as taxi drivers. In this case most of the SMR values were close to unity. Further restriction to those who had been members of the cooperative did not change these results noticeably.

Table 5 shows the results when the cohorts were divided according to duration of employment. In this analysis a latency period of 30 years was applied. Only mortality from lung cancer is shown. The SMR was high among the truck drivers in the group which had the shortest duration of employment. In the group which had worked two to ten years the SMR for lung cancer was also high; however, the SMR for respiratory diseases was low (1 observed, 5.3 expected, not
Table 5. Standardized mortality ratio (SMR) and the $95 \%$ confidence interval $(95 \% \mathrm{Cl})$ for malignant neoplasms of the trachea, bronchus, and lung (ICD-7, 162, 163) for 570 truck drivers (person-years 7003.5) and 348 taxi drivers (person-years 3110.5 ) by duration of employment. A latency period of 30 years has been accounted for. (ICD-7 = seventh revision of the International Classification of Diseases)

\begin{tabular}{lcclll}
\hline \multirow{2}{*}{$\begin{array}{l}\text { Duration of } \\
\text { employment }\end{array}$} & \multicolumn{2}{c}{ Truck drivers } & & \multicolumn{2}{c}{ Taxi drivers } \\
\cline { 2 - 3 } & SMR & $95 \% \mathrm{Cl}$ & & SMR & $95 \% \mathrm{Cl}$ \\
\hline$<2$ years & 2.70 & $0.74-6.92$ & & 0 & \\
$2-10$ years & 2.46 & $0.99-5.08$ & & 0.59 & $0.02-3.30$ \\
$11-30$ years & 0.68 & $0.01-3.76$ & & 0 & - \\
$>30$ years & 2.32 & $0.85-5.04$ & & 1.60 & $0.33-4.66$ \\
\hline Total & 2.09 & $1.32-3.13$ & & 0.84 & $0.23-2.16$ \\
\hline
\end{tabular}

shown in the table). For the group which had worked as truck drivers for 11 to 30 years, the SMR was low, and the SMR for respiratory diseases was also low (2 observed, 5.7 expected, not shown in the table). For those who had worked longer than 30 years, the SMR was high. The results for all truck drivers showed, as before, that mortality due to lung cancer was higher than expected and mortality for respiratory diseases (not shown in the table) was low.

When the subcohort of taxi drivers was analyzed according to duration of employment (table 5), the SMR values did not, in any case, deviate substantially from unity.

Table 6 shows the SMR for lung cancer among the truck drivers grouped according to the length of 
the follow-up period. There was no indication of a steadily increasing SMR as the follow-up period became longer.

Table 7 shows the smoking habits of the taxi and truck drivers and all the subjects who participated in the Hjartavernd study. Among the truck drivers there were fewer, proportionally, who had never smoked than among all the participants, while more of the truck drivers had stopped smoking or smoked cigars or pipes. The proportion of truck drivers who smoked cigarettes was similar to that of the group in general, but there were fewer among the truck drivers who smoked 15 cigarettes or more daily.

The smoking habits of the taxi drivers according to the information from Hjartavernd are similar to the smoking habits of the other participants in the Hjartavernd study.

\section{Discussion}

In this study we decided to treat truck drivers and taxi drivers separately in order to evaluate whether some type of strain or exposure involved in either of these occupations could lead to certain causes of death.

The main result of this study with respect to the truck drivers was the high mortality due to lung cancer (SMR 2.14). The SMR was higher than that obtained in a recent cohort study of truck drivers in the United Kingdom (2), but the ratio was lower than has been obtained in a case-referent study (6). In addition, the SMR for respiratory diseases was low for the truck

Table 6. Standardized mortality ratio (SMR) and the $95 \%$ confidence interval $(95 \% \mathrm{Cl})$ for malignant neoplasms of the trachea, bronchus, and lung (ICD-7, 162, 163) for 868 truck drivers by follow-up period. (ICD-7 = seventh revision of the International Classification of Diseases)

\begin{tabular}{lcc}
\hline Period of follow-up & SMR & $95 \% \mathrm{Cl}$ \\
\hline $0-9$ years & 4.76 & $0.12-26.53$ \\
$10-19$ years & 4.17 & $0.86-12.18$ \\
$20-29$ years & 1.00 & $0.12-3.61$ \\
$30-39$ years & 3.38 & $1.89-5.57$ \\
$40-49$ years & 0.63 & $0.08-2.27$ \\
$\geq 50$ years & 1.49 & $0.04-8.28$ \\
\hline
\end{tabular}

drivers (SMR 0.50). This finding conflicts with the results of the British study (2), which obtained a high SMR for all respiratory diseases and for bronchitis, emphysema, and asthma.

More smoking among truck drivers than among men in general could perhaps provide a partial explanation of the higher mortality due to lung cancer among the truck drivers. The SMR for lung cancer did not increase in proportion to the duration of employment. This finding indicates that smoking might be a confounding factor in this study. According to the findings from the survey of $\mathrm{Hjartavernd}$ (table 7), it is unlikely that the difference between the smoking habits of the truck drivers and other men was enough to explain the higher mortality due to lung cancer among the truck drivers. Fewer deaths from respiratory diseases than expected support this conclusion (25).

It has been suggested that smoking among drivers could be regarded as a special case because of the lack of air circulation in their vehicles, the result being that drivers are subject to more indirect exposure from tobacco smoke than are others who smoke on the job (3).

It is interesting to see the high SMR for lung cancer in the group of truck drivers which had the shortest duration of employment. Of course the explanations should not be sought for in their work environment as a truck driver but perhaps rather in their life-style.

Information on the death certificates regarding the occupation of the decedents (table 2) indicates that it would hardly be desirable to carry out a proportionate mortality study based on the death certificates as such a procedure would lead to serious bias.

When the taxi drivers are considered as a group, there seems to be little evidence that they were at any special risk; however the absence of the healthy worker effect in the cohort is interesting. When the taxi drivers were divided into subcohorts according to duration of employment, the low SMR values generally did not deviate to any great extent from unity.

The SMR for stomach cancer among drivers was not high in this study, and this finding contradicts the results obtained with British drivers (2).

The SMR for bladder cancer was not high for either the taxi or the truck drivers in the present study, and

Table 7. Smoking habits according to the results of the survey made by the National Association for the Prevention of Heart Diseases, Hjartavernd, in 1974 to 1976, of 143 truck drivers and 151 taxi drivers who were members of the cohorts and of all the participants in the survey of Hjartavernd.

\begin{tabular}{|c|c|c|c|c|c|c|}
\hline \multirow{2}{*}{ Smoking habits } & \multicolumn{2}{|c|}{$\begin{array}{l}\text { Truck drivers } \\
\qquad(\mathrm{N}=143)\end{array}$} & \multicolumn{2}{|c|}{$\begin{array}{l}\text { Taxi drivers } \\
(N=151)\end{array}$} & \multicolumn{2}{|c|}{$\begin{array}{l}\text { All participants } \\
(N=5555)\end{array}$} \\
\hline & $\mathbf{N}$ & $\%$ & $\mathbf{N}$ & $\%$ & $N$ & $\%$ \\
\hline Never a smoker & 17 & 11.9 & 34 & 22.5 & 1264 & 22.8 \\
\hline Ex-smoker & 40 & 28.0 & 33 & 21.9 & 1337 & 24.1 \\
\hline Pipe or cigar smoker & 46 & 32.2 & 45 & 29.8 & 1456 & 26.2 \\
\hline Cigarette smoker & 40 & 28.0 & 39 & 25.8 & 1498 & 27.0 \\
\hline $\begin{array}{r}1-14 \text { cigarettes } / d \\
\geq 15 \text { cigarettes } / d\end{array}$ & $\begin{array}{l}19 \\
21\end{array}$ & $\begin{array}{l}13.3 \\
14.7\end{array}$ & $\begin{array}{r}9 \\
30\end{array}$ & $\begin{array}{r}6.0 \\
19.9\end{array}$ & $\begin{array}{l}546 \\
952\end{array}$ & $\begin{array}{r}9.8 \\
17.1\end{array}$ \\
\hline
\end{tabular}


there were only few deaths from bladder cancer. This result suggests a minor effect attributable to smoking among the drivers, as the SMR for bladder cancer and some other smoking-related disorders was low (26).

Although the SMR for cancer of the kidneys turned out to be high in several subcohorts, as was also the case regarding cancers of the lymphatic and hematopoietic tissues, these results were so internally inconsistent that no definite conclusions can be drawn from them.

In the present study there was excess mortality due to lung cancer, more prominent among the truck drivers. It is possible that one or more factors connected with truck drivers' work, for example, exhaust gases containing carcinogenic substances $(27,28)$, could have resulted in more deaths due to lung cancer in this group. In a recent study on bus garage workers, which might have had work conditions similar to those of the truck drivers in the present study, the focus was set on exposure to diesel exhaust and asbestos, and the results were thought to indicate that exposure to diesel exhaust increases the risk of lung cancer (29).

\section{Acknowledgments}

We thank Dr N Sigfússon for information from the National Association for the Prevention of Heart Diseases, Hjartavernd, and the Truck Drivers' Union Thróttur and the Cooperative Taxi Agency Hreyfill for their generous assistance and valuable information.

\section{References}

1. Luepker RV, Smith ML. Mortality in unionized truck drivers. J Occup Med 1978;20:677-82.

2. Balarajan R, McDowall ME. Professional drivers in London: a mortality study. Br J Ind Med 1988;45: 483-6.

3. Ahlberg J, Ahlbom A, Lipping H, Norell S, Österblom L. Cancer hos yrkeschaufförer - problemorienterad registerstudie [Cancer among professional drivers problem oriented register study]. Läkartidningen 1981; 15:1545-6.

4. Netterström B. Cancer incidence among urban bus drivers in Denmark. Int Arch Occup Environ Health 1988;61:217-21.

5. Buell P, Dunn JE, Breslow L. The occupational-social class risks of cancer mortality in men. $\mathrm{J}$ Chronic Dis 1960;12:600-21.

6. Damber L, Larsson LG. Professional driving, smoking, and lung cancer: a case referent study. $\mathrm{Br} \mathrm{J}$ Ind Med 1985;42:246-52.

7. Silverman DT, Hoover RN, Albert S, Graff KM. Occupation and cancer of the lower urinary tract in Detroit. J Natl Cancer Inst 1983;70:237-45.

8. Baxter PJ, McDowall ME. Occupation and cancer in London: an investigation into nasal and bladder cancer using the Cancer Atlas. Br J Ind Med 1986;43:44-9.

9. Hoar SK, Hoover R. Truck driving and bladder cancer mortality in rural New England. J Natl Cancer Inst 1985;74:771-4.

10. Howe GR, Burch JD, Miller AB, et al. Tobacco use, occupation, coffee, various nutrients, and bladder can- cer. J Natl Cancer Inst 1980;64:701-13.

11. Wynder EL, Onderdonk J, Mantel N. An epidemiological investigation of cancer of the bladder. Cancer 1963;16:1388-407.

12. Jensen OM, Wahrendorf J, Knudsen JB, Sörensen BL. The Copenhagen case-referent study on bladder cancer: risks among drivers, painters and certain other occupations. Scand J Work Environ Health 1987;13:129-34.

13. Dunham LJ, Rabson AS, Stewart HL, Frank AS, Young JL. Rates, interview, and pathology study of cancer of the urinary bladder in New Orleans, Louisiana. J Natl Cancer Inst 1968;41:683-709.

14. Anthony HM, Thomas GM. Tumors of the urinary bladder: an analysis of the occupations of 1,030 patients in Leeds, England. J Natl Cancer Inst 1970;45:879-95.

15. Rushton L, Alderson MR. Epidemiological survey of oil distribution centres in Britain. Br J Ind Med 1983; 40:330-9.

16. Howe GR, Lindsay JP. A follow-up study of a tenpercent sample of the Canadian labor force: I. cancer mortality in males, 1965-73. J Natl Cancer Inst 1983; 70:37-44.

17. Jónsson I. Mað̛ur og billl: Vörubílstjórafélagið próttur. Saga og félagatal 1931-1987 [Man and vehicle: the truck drivers' union Thróttur: the history of the union and a membership list 1931-1987). Reykjavík: Vörubílstjórafélagiő próttur, 1987.

18. Jónsson I. Hreyfilsmenn: Saga og félagatal 1943-1988 [The men in Hreyfill: The history of the agency and a membership list 1943-1988). Reykjavík: Hreyfill, 1988.

19. Waxweiler RJ, Beaumont JJ, Henry JA, et al. A modified life-table analysis system for cohort studies. J Occup Med 1983;25:115-24.

20. MacMahon B, Pugh TF. Epidemiology, principles and methods. Boston, MA: Little, Brown and Company, 1970.

21. Axelson O. Epidemiologi för arbets- och miljömedicin [Epidemiology for occupational and environmental medicine]. Lund: Studentlitteratur, 1981.

22. Rafnsson V, Gunnarsdóttir H. Mortality study of fertiliser manufacturers in Iceland. Br J Ind Med 1990;47: $721-5$.

23. Swaen GHM, Volovics A. Investigating dose response relations in occupational mortality studies: something to keep in mind. Br J Ind Med 1987;44:642-4.

24. Hjartavernd. Atvinna, húsnæði, heilsufar og félagslegar aðstæður 16 starfsflokka karla á höfuðborgarsvæðinu á aldrinum 41-68 ára: Hóprannsókn Hjartaverndar 1974-'76: rit C XXI [Occupation, residen$\mathrm{cy}$, health and social situation of 16 occupational groups of men in the capital area in the ages $41-68$ years: the survey of the National Association for the Prevention of Heart Diseases 1974-76: report C XXI]. Reykjavík: Hjartavernd, 1989.

25. Axelson $\mathrm{O}$. Confounding from smoking in occupational epidemiology (Editorial). Br J Ind Med 1989;46:505-7.

26. Steenland K, Beaumont J, Halperin W. Methods of control for smoking in occupational cohort mortality studies. Scand J Work Environ Health 1984;10:143-9.

27. Boffetta P, Stellman SD, Garfinkel L. Diesel exhaust exposure and mortality among males in the American Cancer Society Prospective Study. Am J Ind Med 1988; 14:403-15.

28. Schenker MB. Diesel exhaust - an occupational carcinogen? J Occup Med 1980;22:41-6.

29. Gustavsson P, Plato N, Lidström E-B, Hogstedt C. Lung cancer and exposure to diesel exhaust among bus garage workers. Scand J Work Environ Health 1990;16:34854.

Received for publication: 19 November 1990 